Conference Proceedings Paper

\title{
The Buenaventura Sector of the San Finx W-Sn deposit (NW Spain): ore mineralogy, host rocks and associated hydrothermal alteration.
}

David Garófano Medina ${ }^{1}$, Mercedes Fuertes-Fuente ${ }^{1, *}$, Antonia Cepedal ${ }^{1}$, and Agustín MartinIzard 1

1 Department of geology, University of Oviedo, Arias de Velasco s/n, 33005 Oviedo, Spain; garofanodavid@gmail.com (D.G.M.); mcepedal@ uniovi.es (A.C.); amizard@uniovi.es (A.M.-I.)

* Correspondence: mercedf@uniovi.es

Received: date; Accepted: date; Published: date

\begin{abstract}
The San Finx W-Sn ore deposit is located in the Spanish province of A Coruna (Galicia, NW Spain). Geologically, it occurs in the Galicia-Trás-os-Montes Zone which is one of the innermost zones of the Iberian Variscan collisional belt. This ore deposit is characterized by NE-SW trending quartz-dominated veins with centimeter size hübnerite and cassiterite. This research focuses on one sector of this deposit known as Buenaventura. The aim of this work is to present a mineralogical and petrological characterization of the ore-bearing veins, their host-rocks and associated hydrothermal alteration. The vein mineralogy is mainly quartz, muscovite, K-feldspar, apatite and scarce fluorite. The ore minerals are hübnerite, scheelite and cassiterite with columbite and ilmenorutile-struverite inclusions, together with sulfides, mainly chalcopyrite and arsenopyrite, and in less abundance, molybdenite, löllingite, pyrrhotite, sphalerite, stannite, pyrite, $\mathrm{Bi}-\mathrm{Pb}-\mathrm{Ag}$ sulfosalts and native bismuth. The main host-rocks are micaschist and paragneiss and two types of pegmatites, homogeneous pegmatites and banded aplite-pegmatites with columbite. The host rocks are affected by four types of hydrothermal alterations: tourmalinization, greissenization, feldspathization and silicification. The more widespread alteration is the feldspathization in which the protolith is replaced by massive albite and K-feldspar with fibrous habit, accompanied by apatite, chlorite, rutile, magnetite, hematite, chalcopyrite, and sphalerite. In addition, there are highly deformed areas with a complex alteration rich in K-feldspar and sulfides, mainly chalcopyrite, minerals of the stannite group, and sphalerite, in less abundance, bismuthinite, native bismuth, galena and pyrite. This deposit shares features in terms of geological setting, hydrothermal alteration and ore assemblages with exogreisen systems formed in the cupolas of highly fractionated granites in collisional settings.
\end{abstract}

Keywords: W-Sn ore; tourmalinization; greissenization; feldspathization; columbite-bearing pegmatites; NW Iberia.

\section{Introduction}

The demand for tin and tungsten has increased over the last decade, tin due to its variety of uses in new technologies. Tungsten is a strategic metal that has been on the EU's list of Critical Raw Materials since it released the first one in 2011. The Sn-W metallogenic province of the European Variscan Belt contains numerous Sn-W ore fields associated with highly evolved Variscan S-type granites. In this work, we focus on an Sn-W deposit, the San Finx Mine (Galicia, Spain), located in NW Iberia, within the southern part of the above-mentioned metallogenic province. The San Finx Mine was opened in 1884, being one of the first tungsten mining operations in Europe. Since then, the mine has closed and reopened several times; it has been in mining operation for the last decade. 
The deposit is a system of ore-bearing quartz veins with a lateral extension of around $3.5 \mathrm{Km}$ [1] and has been divided into four exploitation areas, the Buenaventura Sector being the earternmost $[1,2]$. The aim of this work is a mineralogical and petrological characterization of the ore-bearing veins, their host-rocks and associated hydrothermal alteration in the Buenaventura Sector.

\subsection{Geological Setting}

The study area is located in the Galicia-Trás-Os-Montes Zone (GTMZ), one of the zones into which the NW Iberian Variscan belt was divided [3]. The GTMZ comprises a pile of units thrust over the autochthonous Central Iberian Zone. The San Finx Deposit is located at the bottom of the allochthonous pile (Figure 1). The tectonic style of the GTMZ is dominated by a thrust regime with two Variscan deformation events associated with the nappe emplacements. After nappe emplacements, subvertical axial-plane folds and shear zones typify a last deformation event (D3), and the emplacement of synkinematic two-mica peraluminous granites, like those outcropping east of the studied area. A postkinematic, shallow-level granitoid also outcrops south of the San Finx Deposit. Fault systems related to the late Variscan extensional phase are widespread in the study area.

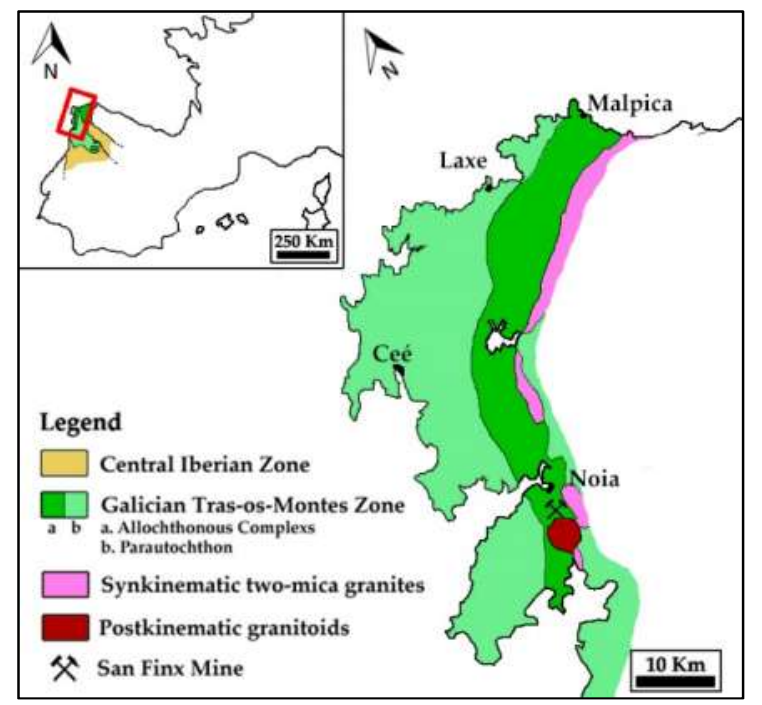

Figure 1. Geological map of the NW Iberian Variscan belt showing the location of the San Finx W-Sn Deposit in the Galicia-Trás-Os-Montes Zone, modified from [4,5].

\section{Materials and Methods}

The studied samples were collected from the ore veins and from the different lithotypes occurring in the underground mine of the Buenaventura sector in the San Finx deposit. The sample suite was studied by optical and scanning electron microscopy (SEM) using a JEOL-6610LV in association with an energy dispersive X-ray spectrometer (EDS) for chemical microanalysis (INCA Energy 350-Xmax 50). Representative samples were chosen for mineral microanalysis using an electron microprobe (EMP), Cameca SX100. The EMP analytical conditions of phosphates and silicates were $15 \mathrm{kV}, 15 \mathrm{nA}$, and those of oxides were $10 \mathrm{kV}, 30 \mathrm{nA}$, with an acquisition time of 20s Xray peak and background. These analyses were done at the Scientific and Technical Services of the University of Oviedo (Spain).

\section{Results}

In the Buenaventura Sector, mica-schist and, less commonly, paragneiss, host ore veins and pegmatite dykes, and undergo different hydrothermal alterations. 


\subsection{Ore veins}

The mineralized structures are a system of quartz veins with an average strike of N50E, dipping around $80^{\circ}$ to the South. Most of them have a thickness of around 1-1.5 meters $[1,2,6]$.

As regards vein mineralogy, apart from quartz, the second-most abundant silicate is white mica. These major components, together with other minerals, infill the veins in a banded distribution almost parallel to the vein contact (Figure 2a,b). At the edge of the veins, there is a thin layer $(<0.5$ $\mathrm{cm}$ ) of fluorapatite, K-feldspar (Figure 3a) and fine-medium grained white mica. The latter is frequently intergrown with fine-medium grained molybdenite. In addition, pyrite, chalcopyrite, fluorite and $\mathrm{Bi}-\mathrm{Pb}$-Ag sulfosalts occur in minor proportions. From the vein margin towards the centre, the white mica progressively coarsens and becomes more abundant, forming centimetric bands of massive coarse-grained white mica accompanied by mangano-fluorapatite, centimetric euhedral cassiterite and molybdenite. The mangano-fluorapatite, together with chalcopyrite and sphalerite replace the white mica along cleavage planes. In the vein centre, quartz is by far the most abundant mineral, followed by sparsely distributed K-feldspar, coarse-grained white mica and fluorapatite. Centimetric euhedral crystals of wolframite characterize the quartz-rich central part of the veins, as do cassiterite and sulfides. The latter are chiefly chalcopyrite, arsenopyrite and, in lower quantities, molybdenite. Here, the mangano-fluorapatite also occurs intergrown with the white mica and associated with the sulfides. In addition, Mn-richer fluorapatite (Figure 3b) and siderite together with pyrite fill vugs in the ore veins. The white mica composition trend extends from muscovite to ferroaluminoceladonite end-members (Figure 3c) according to the [7] classification.

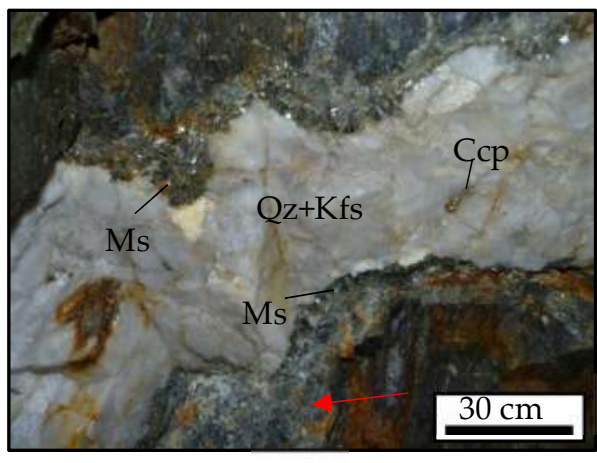

(a)

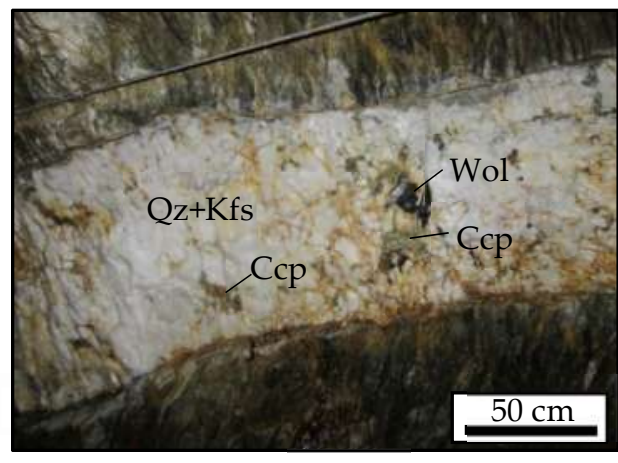

(b)

Figure 2. Ore veins in the underground mine of the Buenaventura Sector: (a) showing a greissenized selvage (red arrow); (b) showing centimetric wolframite crystals. Ms: muscovite, Qz: quartz, Kfs: Kfeldspar, Ccp: chalcopyrite, Wol: Wolframite.

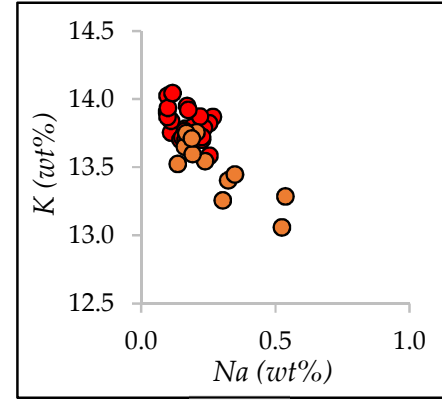

(a)

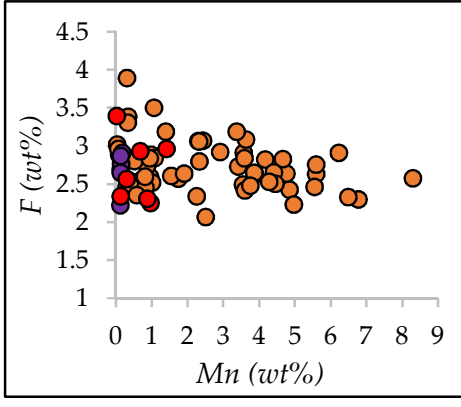

(b)

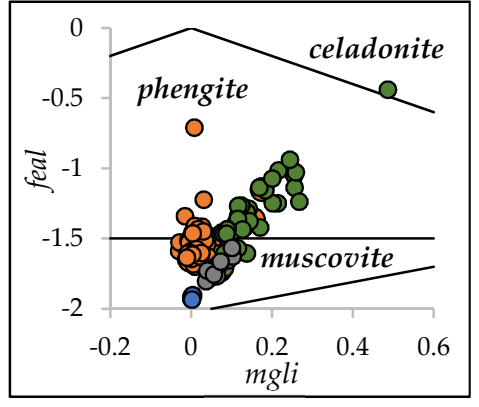

(c)

○ Ore vein ० Banded aplite-pegmatite ○ Mica-schist ○ Greissenization ○ Feldspathization ○ Tourmalinization

Figure 3. Compositional diagrams of minerals from the ore veins and from the different lithotypes: (a) Plot of $\mathrm{Na}(\mathrm{wt} \%)$ vs. K (wt \%) for K-feldspars; (b) Plot of Mn (wt \%) vs. F (wt \%) for fluorapatite; (c) White Mica composition in the classification diagram for K-micas [7]. All data from EMP. 
Where the veins are affected by later faults, the above described minerals are replaced by a complex alteration assemblage, distinctly rich in sulfides, and mainly characterized by K-feldspar, clear euhedral quartz and vermicular chlorite.

\subsection{Pegmatites}

Two types of pegmatite have been differentiated based on the internal structure as well as the mineralogy, designated banded aplite-pegmatites and homogeneous pegmatites. In some sections of the Buenaventura underground mine, it is possible to observe the ore veins crosscutting the homogeneous pegmatites.

The banded aplite-pegmatites are tabular-shaped bodies around $1 \mathrm{~m}$ in width. They lie oblique to the main foliation of the metasedimentary host rocks. The bodies show a banded internal structure parallel to wallrock contacts, and characterized by two bands, a thicker coarse-grained band dominated by K-feldspar and an albite-rich fine-grained band. The former is made up of K-feldspar, quartz, muscovite and, in minor proportion, albite, garnet being an accessory mineral. The albite-rich band shows a magmatic layering characterized by layers dominated by albite (Ab98-99) laths with a preferred orientation, and layers dominated by quartz, K-feldspar and muscovite occurring in lower propotion. The accessory minerals are tourmaline, beryl, fluorapatite and $\mathrm{Nb}$-Ta oxides. EMP analyses allow us to classify the tourmaline as schorl according to the [8] classification (Figure 4a), and the $\mathrm{Nb}$-Ta oxides as columbite-(Fe-Mn) (Figure $4 \mathrm{~b})$.

The homogenous pegmatites are also tabular-shaped bodies around $2 \mathrm{~m}$ in width and lie almost parallel to the main foliation of the host rocks. They are made up of centimetric crystals of poikilitic pertitic K-feldspar, albite, quartz and muscovite surrounded by a fine-grained groundmass with the same mineralogy.

In both pegmatite types, intracrystalline deformation (eg.: deformation twins in albite, undulose extinction and subgrains in quartz and felsdpars) is a common characteristic of their minerals.

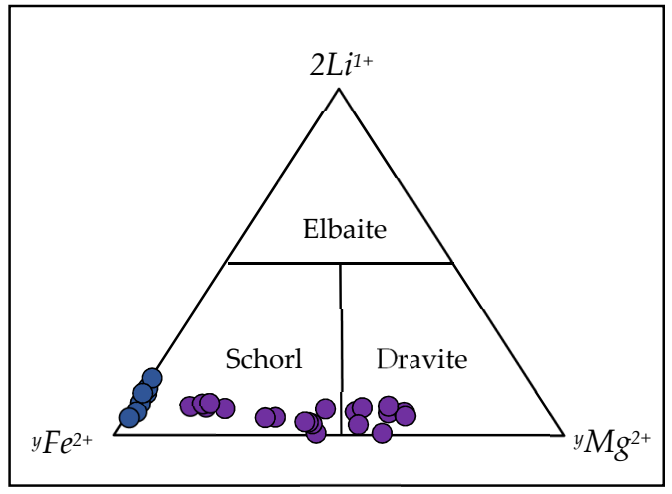

(a)

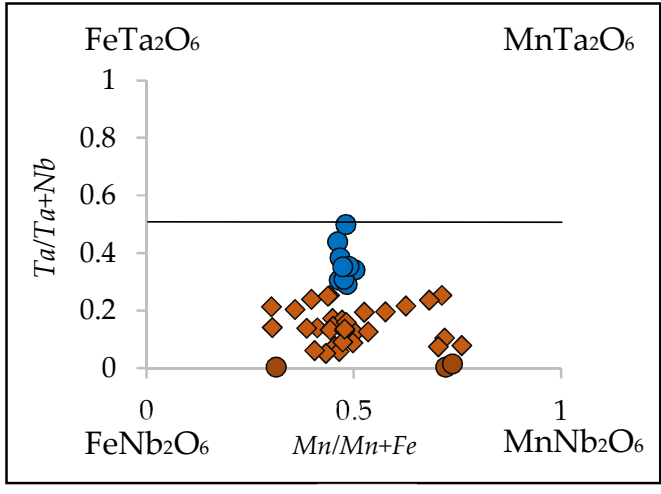

(b)

$\diamond$ Ore vein (SEM-EDS) o Ore vein (EMP) • Banded aplite-pegmatite (EMP) ० Tourmalinization (EMP)

Figure 4. Mineral chemistry classification diagrams: (a) Tourmaline according to the [8] classification; (b) Ta-Nb oxides plotted in the columbite-tantalite quadrilateral, $\mathrm{Mn} /(\mathrm{Mn}+\mathrm{Fe}) \mathrm{vs}$. $\mathrm{Ta} /(\mathrm{Ta}+\mathrm{Nb})$.

\subsection{Hydrothermal alterations of the metasedimentary host-rocks}

The dominant metasedimentary rock is a two-mica (muscovite-biotite) schist with mica-domains alternating with quartz-domains. This schist is affected by four types of hydrothermal alterations, namely tourmalinization, greissenization, feldspathization and silicification.

The tourmalinization sometimes occurs as alteration halos developed along schist-ore vein contacts. The long axes of the tourmaline are oriented parallel to the main foliation of the mica schist. Under optical microscopy, the crystals show a colour zoning with blue cores and brown rims. From EMP analyses, the tourmaline composition varies from dravite cores to schorl rims (Figure 4a). The borosilicate is accompanied by fluorapatite (Figure $3 b$ ) and W-bearing rutile with up to 5 wt \% W 
from EMP analyses. [9] also point out the presence of $\mathrm{W}$-rich rutile in tourmalinized wallrock of the world-class Panasqueira W-Sn-(Cu) ore deposit (Portugal).

The greissenization occurs in the selvages of the ore veins (Figure 2a). It is mainly characterized by aggregates of misoriented fine-grained $(20-40 \mu \mathrm{m})$ white mica which, along with fluorapatite, clearly overprint the mica schist mineralogy. The white mica composition trend extends from muscovite to aluminoceladonite end-members (Figure 3c). Pyrite and minor chalcopyrite are also present. This alteration overprints the tourmalinized wallrocks described above.

The more widespread alteration is the feldspathization that produces fine-grained masses of albite (Ab97-99) and K-feldspar. The feldspathized areas are often surrounded by a silicified mica schist halo (Figure 5a). Where the alteration is not pervasive, it is possible to observe that the schist quartzdomains are replaced by idiomorphic albite whereas the schist mica-domains are replaced by Kfeldspar with a fibrous habit and by chlorite with some biotite relicts. In areas of pervasive feldspathization, the metamorphic fabric is unrecognizable, and the albite coarsens and increases its proportion with regards to that of the K-feldspar, locally forming albitites. In addition, strong intracrystalline deformation in the feldspars is noticeable. The main accessory minerals are fluorapatite (Figure 3b) and zircon, together with oxides and sulfides. The last two are rutile, hematite, magnetite, sphalerite and chalcopyrite. These minerals often occur as assemblages of subidiomorphic to idiomorphic crystals in which hematite and magnetite are embedded by chalcopyrite and sphalerite. EMP analyses of the rutile, which usually occurs associated with the hematite, show between 0.3 and $1.8 \mathrm{wt} \% \mathrm{Nb}$. In areas of pervasive feldspathization, local breccias occur with a later generation of coarser-grained and purest albite (Ab99) overgrowing the feldspathized clasts, which have chlorite filling open spaces (Figure $5 b$ ). The breccia cement is vermicular chlorite and coarse-grained clear subeuhedral-euhedral quartz together with scarcer fluorite and pyrite. Siderite and K-feldspar, frequently showing cross-hatched twinning, together with the mineral assemblage of this cement also occur as vug infills in feldspathized areas without brecciation. From EMP data, chlorite in the feldspathized areas is mainly pycnochlorite whereas in breccias is iron-richer ripidiolite, according to the [10] classification.

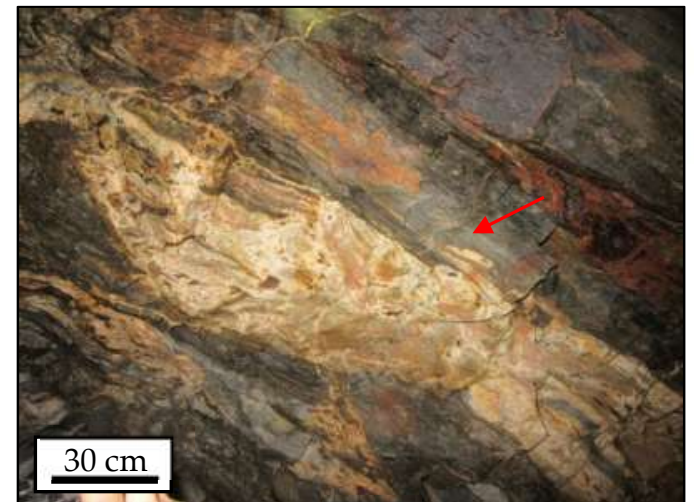

(a)

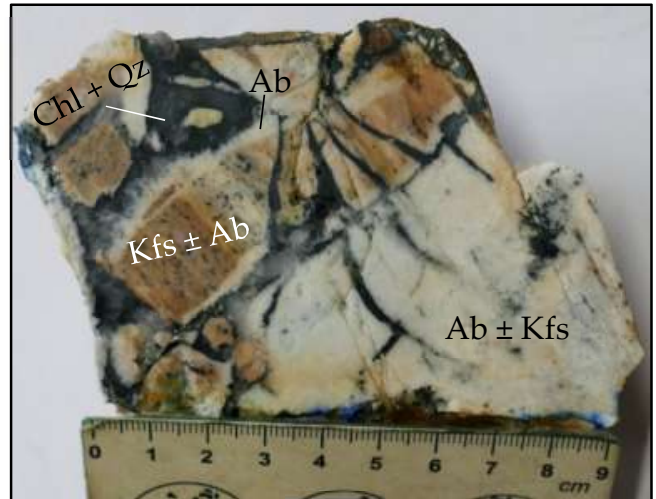

(b)

Figure 5. Feldspathized areas in the underground mine of the Buenaventura Sector: (a) partly feldspathized mica schist surrounded by a halo of silicification (red arrow). (b) breccia of feldspathized clasts in a cement of chlorite and quartz. Note a later albite-rim around the central clast. Ab: albite, Qz: quartz, Kfs: K-feldspar, Chl: chlorite.

\subsection{Ore paragenesis}

The main ore minerals are wolframite and cassiterite with inclusions of $\mathrm{Nb}$-Ta-Ti oxides, together with sulfides, mainly chalcopyrite and arsenopyrite, and molybdenite, sphalerite and stannite in lower proportion. Pyrite, löllingite, pyrrhotite, Bi-Pb-Ag sulfosalts, native bismuth, bismuthinite and galena occur in minor quantities 


\subsubsection{Wolframite and cassiterite.}

Wolframite mainly occurs in the quartz-rich central part of the veins (Figure 2b). From EMP analyses, this oxide is the Mn-rich member hübnerite with an average structural formula ( $\left.\mathrm{Mn}_{0.71} \mathrm{Fe}_{0.25} \mathrm{Nb}_{0.01}\right)_{\mathrm{WO}_{4}}$. It is often replaced by scheelite.

As regards cassiterite, two stages of deposition have been distinguished. The volumetrically most important is represented by the euhedral centimetric cassiterite crystals (Cst 1 ) of the ore veins. A later stage is characterized by dendritic aggregates of fine-grained cassiterite (Cst 2 ) embedded in euhedral clear quartz in the aforementioned complex alteration assemblage that locally replaced the ore vein.

The cassiterite Cst 1 shows optical zoning and EMP analyses reveal to be quite pure with low contents of $\mathrm{Nb}(0.5-0.8 \mathrm{wt} \%)$, Ta $(0.2 \mathrm{w} \%)$, Fe $(0.2 \mathrm{wt} \%)$ and $\mathrm{Ti}(0.1 \mathrm{wt} \%)$. It has abundant tiny $(<$ $100 \mu \mathrm{m}$ ) inclusions of $\mathrm{Nb}$-Ta-Ti oxides. EMP and SEM-EDS analyses allow us to classify some of them as columbite-(Fe) and columbite-(Mn) (Figure $4 \mathrm{~b})$. In addition, some inclusions are aggregates of columbite and a member of the ilmenorutile-strüverite series closer to the Ta-rich member (Figure 6a). The calculated structural formula is ( $\left.\mathrm{Ti}_{0.78} \mathrm{Fe}_{0.10} \mathrm{Ta}_{0.08} \mathrm{Nb}_{0.04} \mathrm{Sn}_{0.01}\right)_{\Sigma 1.01} \mathrm{O}_{2}$. However, it must be taken with caution since it has been calculated from SEM-EDS analyses in tiny inclusions in cassiterite. The cassiterite Cst 2 is inclusion-free and only minor Ta contents (0.7 wt \%) were detected by SEM-EDS analyses. This cassiterite is associated with iron-poor sphalerite, lower than $2 \mathrm{wt} \%$ Fe, from SEM-EDS data.

\subsubsection{Chalcopyrite}

Chalcopyrite is the most abundant sulfide and sometimes occurs as coarse-grained crystals and aggregates (centimetric in size) enclosing abundant inclusions of other sulfides, mainly sphalerite and stannite (Figure 6b). Relicts of the cassiterite Cst 1 embedded in and partially replaced by the chalcopyrite are common (Figure 6c). The stannite occurs in bands as fine-grained acicular inclusions with some scattered rounded inclusions (Figure 6b). Moreover, there are coarser-grained subrounded aggregates of this mineral, with fine-grained sphalerite inclusions mainly located at the contact with the surrounding chalcopyrite. BSE images and SEM-EDS analyses show that it is a Znrich member of the stannite group, probably zincian stannite, with a compositional zoning characterized by a decrease in $\mathrm{Zn}$ and increase in Fe towards the border of the crystals (Figure 7a). This supports the idea that the sphalerite inclusions at the border are an exolution product of the stannite. Coarse-grained sphalerite also occurs embedded in chalcopyrite with abundant rounded inclusions of the latter sulfide (Figure 6c). From SEM-EDS analyses, this sphalerite has contents of around $4 \mathrm{wt} \% \mathrm{Fe}$. Some pyrite and molybdenite also occur surrounded by the chalcopyrite. Moreover, chalcopyrite has micrometre-scale inclusions of bismuthinite, and of galena intergrown with native bismuth. Galena has around $1 \mathrm{wt} \%$ of selenium from SEM-EDS analyses.

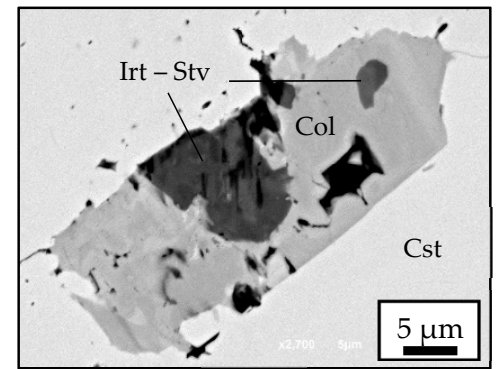

(a)

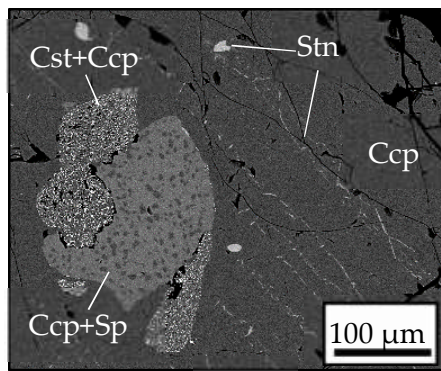

(b)

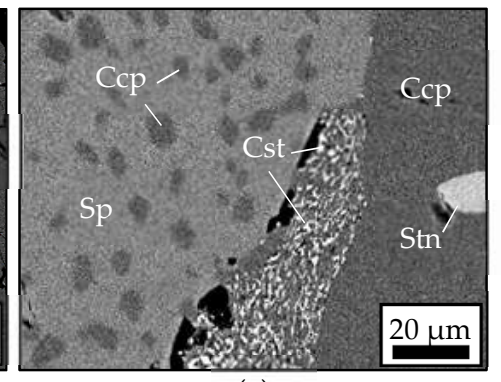

(c)

Figure 6. BSE images of the ore paragenesis: (a) Inclusions of $\mathrm{Nb}$-Ta-Ti oxides in cassiterite; (b) Chalcopyrite with inclusions of other sulfides and cassiterite. (c) The enlarged field of (b) image showing cassiterite partially replaced by the chalcopyrite. Irt-Stv: member of ilmenorutile-strüverite series, Col: columbite, Cst: cassiterite, Ccp: chalcopyrite, Stn: stannite, Sp: sphalerite. 


\subsubsection{Arsenopyrite}

Arsenopyrite often occurs near tourmaline, in tourmaline-rich vein selvages as well as in disrupted fragments of tourmalinized wallrock enclosed in the ore veins.

This mineral has löllingite relicts and abundant inclusions of chalcopyrite, pyrrothite, sphalerite, stannite and micrometer-scale native bismuth. In some inclusions, pyrrothite forms aggregates with sphalerite and stannite. The sphalerite has around $10 \mathrm{wt} \%$ Fe from SEM-EDS analyses. The löllingite has contents of around $1.5 \mathrm{wt} \% \mathrm{Ni}$ and up to $0.8 \mathrm{wt} \% \mathrm{Co}$, and up to $2.8 \mathrm{wt} \% \mathrm{~S}$ from SEM-EDS analyses. From the BSE images (Figure $7 \mathrm{~b}$ ), it is possible to distinguish a first stage of Ni-Co-bearing löllingite, demarcated by native bismuth inclusions, surrounded by a second stage of S-richer löllingite.

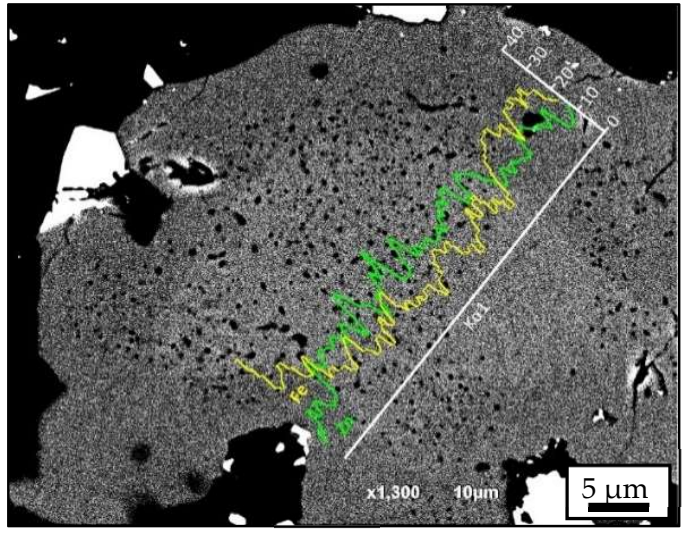

(a)

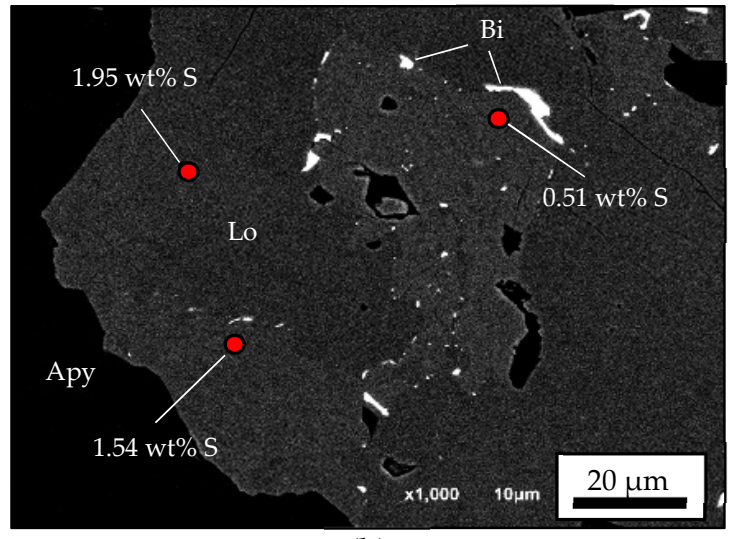

(b)

Figure 7. SEM-EDS data and BSE images of the ore paragenesis: (a) Compositional zoning of stannite with decrease in $\mathrm{Zn}$ and increase in Fe towards the border of the crystal; (b) A löllingite relict in arsenopyrite showing an earlier löllingite, demarcated by native bismuth inclusions, surrounded by a later S-richer löllingite. Apy: arsenopyrite, Lo: löllingite, Bi: native bismuth.

\section{Discussion and Conclusions}

The results of this study provide a tentative paragenetic sequence with an earlier oxide stage and later sulfide stage. The former is characterized by the precipitation of cassiterite (Cst 1 ), hübnerite, columbite (Fe)-(Mn) and $\mathrm{Nb}-\mathrm{Ta}$ rutile (probably strüverite). In the sulfide stage, two major mineral assemblages, one characterized by $\mathrm{As}-\mathrm{Fe}- \pm \mathrm{S}(\mathrm{Zn}-\mathrm{Cu}-\mathrm{Sn})$ and the other by Cu-Fe-S-(Mo-Zn-Sn), are distinguished. In the former, Ni-Co bearing löllingite is the earliest phase, which is replaced by arsenopyrite. Arsenopyrite is the dominant sulfide and intergrows with pyrrhotite, Fe-rich sphalerite, stannite and chalcopyrite. During the deposition of this mineral assemblage the ore related fluids would have progressed from lower to higher sulphur fugacities, which favoured the precipitation of sphalerite rich in Fe and pyrrhotite. The Cu-Fe-S-(Mo-Zn-Sn) mineral assemblage characterizes the main stage of sulfide precipitation dominated by chalcopyrite together with molybdenite, sphalerite and stannite. A later stage of ore deposition is documented by the dendritic aggregates of fine-grained cassiterite (Cst2) together with iron-poorer sphalerite. A quite similar paragenetic sequence is proposed for the Logrosan Sn-(W) deposit (Spain) by [11]. The greissenization is related to the main ore precipitation. However, the spatial association between arsenopyrite and the tourmalinization may support the idea that löllingite and arsenopyrite precipitated pre-syn the oxide stage, since greissenization overprints local tourmalinized selvages. The feldspathization may contribute to an enrichment in Fe-Cu-Zn in the deposit. The cross-cutting relationships in the mine galleries are not clear enough to assert whether the feldspathization was earlier or later than the other alterations. Finally, the studied pegmatites are probably related to the ore system, the columbite of these bodies being the earliest oxide. 
The Buenaventura Sector of the San Finx W-Sn deposit (NW Spain) shares features in terms of geological setting, hydrothermal alteration and ore assemblages with exogreissen systems formed in the cupolas of highly fractionated granites in collisional settings.

Author Contributions: Conceptualization, D.G.M. and M.F.-F.; methodology, D.G.M. and M.F.-F.; validation, M.F.-F. and A.C.; formal analysis, D.G.M., M.F.-F. and A.C.; investigation, D.G.M., M.F.-F. and A.C.; writingoriginal draft preparation, D.G.M. and M.F.-F.; writing-review and editing, A.C. and A.M.-I.; visualization, D.G.M., M.F.-F. and A.C.; supervision, A.M.-I.; project administration, M.F.-F.; funding acquisition, M.F.-F., A.M.-I. and A.C.

Funding: This research was funded by Ministerio de Economía, Industria y Competitividad, Gobierno de España, project CGL2016-76532R (AEI/FEDER/UE).

Acknowledgments: The authors thank Valoriza Minería S.L. for access to San Finx mine.

Conflicts of Interest: The authors declare no conflict of interest.

\section{References}

1. Ruiz Mora, J.E. Mineralizaciones estannovolframiferas en Noia y Lousame. Estudio Previo. Cad. do Lab. Xeolóxico de Laxe 1982, 3, 595-624.

2. Mangas Viñuela, J.; Arribas Moreno, A. Estudio de las inclusiones fluidas atrapadas en cristales de casiterita y cuarzo del yacimiento de San Finx (La Coruña, España). Boletín de la Sociedad Española de Mineralogía 1989, 12, 241-259.

3. Farias, P.; Gallastegui, G.; González Lodeiro, F.; Marquínez, J.; Martín-Parra, L.M.; Martínez Catalán, J.R.; de Pablo Maciá, J.G.; Rodríguez Fernádez, L.R. Aportaciones al conocimiento de la litoestratigrafía y estructura de Galicia Central. Memoria Facultade de Ciencias Universidade do Porto 1987, 1, 411-431.

4. Pérez-Estaún, A.; Bea, F. Macizo Ibérico. In Geología de España; Vera, J.A., Ed.; Sociedad Española de Geología-Instituto Geológico y Minero de España: Madrid, Spain, 2004; pp. 19-230.

5. Llana Fúnez, S. La estructura de la unidad de Malpica-Tui (Cordillera Varisca en Iberia), Publicaciones del Instituto Geológico y Minero: Serie Tesis Doctorales 1; Instituto Geológico y Minero de España: Madrid, Spain, 2001; pp. 1-295.

6. Rodríguez-Terente, L.; Fernández-González, M.; Losada-García, I. Estudio cristalográfico de la Bertrandita de las minas de San Finx (A Coruña, España). In Macla 19 Proceedings of the XXXIV Reunión Científica de la Sociedad Española de Mineralógía, Granada, Spain, 2014; Morales Ruano, S., Gervilla Linares F., Torres Ruiz, J., Eds.; Sociedad Española de Mineralogía: Madrid, Spain.

7. Tischendorf, G.; Rieder, M.; Förster, H.J.; Gottesmann. B. Y.; Guidotti, CH.V. A new graphical presentation and subdivision of potassium micas. Mineral. Mag. 2004, 68(4), 649-667. https://doi.org/10.1180/0026461046840210

8. Henry, D. J.; Novák, M.; Hawthorne, F.C.; Ertl, A.; Dutrow, B.; Uher, P.; Pezzotta, F. Nomenclature of the torumaline-supergroup minerals. Amer. Miner. 2011, 6, 895-913. https://doi.org/10.2138/am.2011.3636

9. Carocci, E.; Marignac, C.; Cathelineau, M.; Truche, L.; Lecomte, A.; Pinto, F. Rutile from Panasqueira (Central Portugal): An Excellent Pathfinder for Wolframite Deposition. Minerals 2019, 9, 9. https://doi.org/10.3390/min9010009

10. Hey, M. H. A new review of chlorites. Mineral. Mag. 1954, 30 (224), 277-292. https://doi.org/10.1180/minmag.1954.030.224.01

11. Chicharro, E.; Boiron, M.C.; López-García, J.A.; Barfod, D.N.; Villaseca, C. Origin, ore forming fluid evolution and timing of the Logrosán Sn-(W) ore deposit (Central Iberian Zone, Spain). Ore Geol. Rev. 2016, 72 (1), 896-913. https://doi.org/10.1016/j.oregeorev.2015.09.020.

(C) 2020 by the authors. Submitted for possible open access publication under the terms and conditions of the Creative Commons Attribution (CC BY) license (http://creativecommons.org/licenses/by/4.0/). 